Ann. Acad. Med. Siles. (online) 2018; 72: 27-32

eISSN 1734-025X

DOI:10.18794/aams/75133

PRACA ORYGINALNA

ORIGINAL PAPER

\title{
Physical activity level and quality of life in menopausal women
}

\author{
Poziom aktywności fizycznej a jakość życia kobiet w okresie okołomenopauzalnym \\ Beata Naworska', Anna Brzęk², Magdalena Dabrowska-Galas³, Agnieszka Drosdzol-Cop, Violetta Skrzypulec-Plinta5, \\ Czesław Marcisz ${ }^{6}$, Krzysztof Sodowski ${ }^{1}$ \\ ${ }^{1}$ Chair and Department of Perinatology and Oncological Gynecology, School of Health Sciences in Katowice, \\ Medical University of Silesia, Katowice \\ 2Department of Kinesiology, Chair of Physiotherapy, School of Health Sciences in Katowice, \\ Medical University of Silesia, Katowice \\ ${ }^{3}$ Department of Kinesiotherapy and Special Methods, School of Health Sciences in Katowice \\ Medical University of Silesia, Katowice \\ 4Department of Gestational Pathology, Chair of Women's Health, School of Health Sciences in Katowice, \\ Medical University of Silesia, Katowice \\ ${ }^{5}$ Department of Sexuology, Chair of Women's Health, School of Health Sciences in Katowice, \\ Medical University of Silesia, Katowice \\ ${ }^{6}$ Department of Gerontology and Geriatric Nursing, School of Health Sciences in Katowice, Medical University of Silesia
}

\section{ABSTRACT}

INTRODUCTION: Women's awareness of a healthy lifestyle has significantly increased in recent years. However, during menopause the hormonal changes may influence the quality of life. Physical activity can significantly reduce the negative health effects associated with menopause. The aim of this study was to assess physical activity in menopausal women and its influence on the quality of life.

MATERIAL AND METHODS: This study was conducted on 567 women aged 50-60 years. Group A was composed of 223 women, participants of the University of the Third Age, and group B contained 334 women, patients of gynecological wards and outpatient clinics. The physical activity level of all the study participants was assessed using the International Physical Activity Questionnaire (IPAQ) short form. SF-36 was used to assess the quality of life.

RESULTS: The physical activity of the majority of women was at a moderate level $-52.9 \%$ in Group A and $70.2 \%$ in Group B, while $44.8 \%$ of women in Group A and $27.8 \%$ of patients in Group B had a high level of physical activity. There were significant differences between both groups in the physical component summary $(\mathrm{p}<0.0004)$ and mental component summary $(\mathrm{p}<0.0004)$. The physical component summary correlated with the participants' ages. The physical functioning, general health and social functioning increased with a higher level of activity in the main group.

CONCLUSIONS: Menopausal women participate mainly in moderate-intensity physical activity. A higher level of physical activity correlates with a better quality of life.

\section{KEY WORDS}

menopause, physical activity, quality of life, IPAQ, SF-36

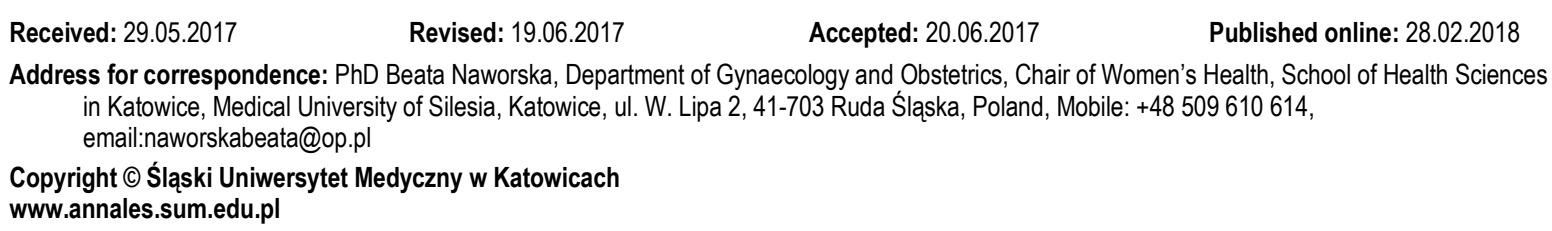




\section{STRESZCZENIE}

WSTĘP: W ostatnich latach znacznie wzrosła świadomość kobiet w różnym wieku na temat zdrowego stylu życia. Okres menopauzy i związane z nim zmiany hormonalne mają wpływ na jakość życia, a odpowiedni poziom aktywności fizycznej może znacząco zmniejszyć negatywne skutki tego okresu. Celem pracy była ocena poziomu aktywności fizycznej kobiet w okresie menopauzy oraz jej wpływu na jakość życia.

MATERIAL I METODY: Badania zostały przeprowadzone u 567 kobiet w wieku 50-60 lat, które włączono do 2 grup. Grupa A obejmowała 223 kobiet, uczestniczek Uniwersytetu Trzeciego Wieku, a Grupa B - 334 kobiety, które były pacjentkami oddziałów ginekologicznych i poradni dla kobiet. Poziom aktywności fizycznej został oceniony z użyciem kwestionariusza aktywności fizycznej IPAQ w wersji krótkiej. Do oceny jakości życia badanych kobiet wykorzystano SF-36.

WYNIKI: Poziom aktywności fizycznej badanych kobiet określono jako umiarkowany w 52,9\% w Grupie A oraz $70,2 \%$ w Grupie B. Wysoki poziom aktywności fizycznej odnotowano u 44,8\% kobiet z grupy A i w 27,8\% z grupy B. Stwierdzono istotne statystycznie różnice pomiędzy kobietami z Grupy A a kobietami z Grupy B w domenach zsumowanej składowej fizycznej ( $<<0,0004)$ oraz zsumowanej składowej psychicznej $(\mathrm{p}<0,0004)$. Wielkość składowej fizycznej korelowała $\mathrm{z}$ wiekiem badanych kobiet. Stan fizyczny, ogólny stan zdrowia i funkcjonowanie w społeczeństwie poprawiały się wraz ze wzrostem poziomu aktywności fizycznej.

WNIOSKI: U kobiet w okresie menopauzalnym przeważa umiarkowany pozom aktywności fizycznej. Wysoki poziom tej aktywności koreluje z lepszą jakością życia.

\section{SŁOWA KLUCZOWE}

menopauza, aktywność fizyczna, jakość życia, IPAQ, SF-36

\section{INTRODUCTION}

Women's awareness of a healthy lifestyle has significantly increased in recent years. However, despite growing public awareness, the lifestyle of many individuals is not changing. Social and psychological factors, including upbringing culture, habits and traditions strengthened throughout many years, sometimes generations, are often an obstacle in the strive for a healthy lifestyle and good quality of life (QoL) [1]. The adverse sedentary lifestyle, dominant in the $21 \mathrm{st}$ century, is the main cause of low levels of physical activity among women. It is the cause of obesity and severity of menopausal symptoms [2]. During menopause, the decreasing concentrations of estradiol reduce the beneficial effects of this hormone on the physical activity level, which is one of the most serious health problems of menopausal women $[3,4,5]$. In addition, the inconveniences of the perimenopausal period associated with hormones diminish the quality of women's life, which in turn manifests in a lack of desire for further development, lower levels of physical and social activity and withdrawal from social life [6].

Physical activity can significantly reduce the negative health effects associated with menopause. It should be stated that physical activity causes numerous physiological adaptive changes preparing the organism for work of varying degrees of intensity. Multiple adaptive changes of the system are observed during exerci- se. A lack of physical activity causes faster aging, deterioration in health and the occurrence of many civilization-related diseases. Physical activity is important in every phase of human life. For adults it is mainly a prophylactic agent improving overall efficiency and QoL [7].

Specific changes in the perimenopausal period are observed in physiological parameters. Women are more vulnerable to gaining body mass and the amount of deposited fat, especially within the abdomen [8]. Emerging problems and dysfunctions result in a bad mood and affect self-acceptance as well as the psychophysical condition. Therefore, it is very difficult for women to initiate any action in this period. Lifestyle, physical activity and a balanced diet improve the quality of women's life, especially in the menopausal period $[9,10]$. Attending group classes at Universities of the Third Age (UTA) may have a substantial impact on women's awareness and increase in their motivation to undertake intellectual and physical activity, which in turn may translate into improved health and QoL.

The research questions are focused on the reasons for the lack of physical activity, the possibility of preventing as well as effectively promoting a healthy lifestyle. These questions are of scientific and societal relevance because they are still unsolved. The problem of reduced physical activity was a very important question that emerged while the hypothesis for this study was being created. This problem has been identified but not solved yet. The research presented in this study is only a part of a larger scientific research project. 
The aim of this study was to assess the level of physical activity in menopausal women and its influence on QoL.

\section{MATERIAL AND METHODS}

\section{Study population}

The survey originally included 1500 questionnaires but due to a number of exclusion criteria the final analysis took into account 567 questionnaires filled by women aged 50-60 years old living in Poland. All the surveyed women were informed about the aim of research, familiarized with the research project and they provided oral consent to participate in the study. The questionnaires were completed by the respondents independently and were completely anonymous. An individual identification number gave the possibility to connect the questionnaires of a given respondent. The main group (Group A) consisted of 223 women aged 53-60 (mean $\pm \mathrm{SD}=58.9 \pm 1.6)$ years old, were attendees of Universities of the Third Age (UTA) in Silesia. The results were compared with a control group (Group B) of 342 randomly selected female patients of gynaecological surgeries and clinics, not attending UTA classes, aged from 50 to 60 (53.2 \pm 2.9) years old (Table I).

Table I. General characteristics of study groups Tabela I. Charakterystyka ogólna badanych grup

\begin{tabular}{|l|c|c|c|c|}
\hline \multirow{2}{*}{ Parameter } & \multicolumn{4}{|c|}{ Investigated groups } \\
\cline { 2 - 5 } & \multicolumn{2}{|c|}{ group A $(\mathbf{n}=\mathbf{2 2 3})$} & \multicolumn{2}{c|}{ group $B(\mathbf{n}=342)$} \\
\cline { 2 - 5 } & mean \pm SD & range & mean \pm SD & range \\
\hline Age $(\mathrm{yrs})$ & $58.9 \pm 1.6$ & $53-60$ & $53.2 \pm 2.9$ & $50-60$ \\
\hline Height $(\mathrm{cm})$ & $162.8 \pm 5.5$ & $150-192$ & $164.2 \pm 6.1$ & $150-186$ \\
\hline Weight $(\mathrm{kg})$ & $71.3 \pm 10.2$ & $43-110$ & $72.6 \pm 11.5$ & $48-120$ \\
\hline BMl $(\mathrm{kg} / \mathrm{m} 2)$ & $26.9 \pm 3.7$ & $16.0-42.9$ & $27.0 \pm 4.4$ & $18.2-42.8$ \\
\hline
\end{tabular}

More than a half of the women was economically active $(52 \%) .32 \%$ of the respondents were citizens of large cities (over 100 inhabitants). 17\% of women came from cities of up to 100 inhabitants, $31 \%$ from small towns, and $20 \%$ lived in rural areas. The majority of participants in both groups have secondary education (52.5\% in Group A and 50\% in Group B), while $25.6 \%$ of Group A and $21.4 \%$ of Group B have a vocational education.

The criteria for inclusion in the study were: the woman's age (50-60 years old), awareness of and voluntary consent to participate in the study and two sets of research questionnaires completed by the respondent. Exclusion criteria from the study were: chronic diseases accompanied by pain, thyroid disease and cancer.

\section{METHODS}

The Five-day International Physical Activity Questionnaire - short form questionnaire (IPAQ-SF) was used to determine the profile of physical activity [11]. The questions concerned physical activity in three domains: walking, moderate-intensity activities, vigorous-intensity activities and sitting. The level of physical activity category (inactive, minimally and hyperactive) of the surveyed women in each of the abovementioned domains was calculated. The metabolic equivalent (MET) intensity values used to score the IPAQ questions in this study were vigorous (8 METs), moderate (4 METs) and walking (3.3 METs).

The SF-36 questionnaire (SF-36v2 - The Medical Outcomes Study - Health Survey Short-Form - SF-36) was used to assess QoL. It was approved and the license number of the Quality Metric Health Survey SF was: QM012681. It concerned analysis of the last four weeks in the lives of the respondents. It consisted of 11 questions containing 36 statements classified into 2 global domains: Physical Component Summary (PCS) and Mental Component Summary (MCS).

\section{Statistical analysis}

The continuous variables are described as the mean \pm standard deviations $(\mathrm{x} \pm \mathrm{SD})$, whereas the categorical variables are described as n (\%). The t-test for dependent variables was used to compare the mean values, the Pearson correlation coefficient was used to evaluate the relations between the $\chi^{2}$ parametric values, Spearman's rank correlation and Mann-Whitney U tests were applied in the case of non-parametric values. The Kolmogorov-Smirnov test was used to test the normality of data distribution. The level of significance $p<0.05$ was applied for all the tests. All the analyses were performed using Statistica software (Statsoft, Poland), v. 12.

\section{RESULTS}

\section{Assessment of physical activity}

The physical activity of the majority of women was at a moderate level $-52.9 \%$ of Group A and $70.2 \%$ of Group B, while $44.8 \%$ of women in Group A and $27.8 \%$ of participants in Group B had a high level of physical activity. Low levels of physical activity were observed in $2.6 \%$ of women in Group A and $2.0 \%$ in Group B. The respondents in Group A sit an average of 224.6 minutes per day, while the women in group B 190.6 minutes per day. The average number of METs of walking, walking, moderate and intense physical activity was higher in Group A (Table II). 
Table II. Physical activity level in studied groups

Tabela II. Poziom aktywności fizycznej w badanych grupach

\begin{tabular}{|l|c|c|c|c|c|}
\hline \multirow{2}{*}{ Variable } & \multicolumn{3}{|c|}{ Investigated women (MET-min/week) } & \multirow{2}{*}{$\begin{array}{c}\text { Statistical significance } \\
\text { of differences (p) }\end{array}$} \\
\cline { 2 - 5 } & \multicolumn{2}{|c|}{ group A ( $\mathbf{n = 2 2 3 )}$} & \multicolumn{2}{c|}{ group B ( $\mathbf{n = 3 4 2 )}$} & \\
\cline { 2 - 5 } & mean \pm SD & range (Median) & mean \pm SD & range (Median) & \\
\hline Vigorous physical activity & $3056 \pm 2172$ & $320-10080(2880)$ & $2572 \pm 2014$ & $240-8640(1920)$ & 0.007 \\
\hline Moderate physical activity & $1131 \pm 988$ & $60-5040(900)$ & $948 \pm 888$ & $40-5040(480)$ & 0.003 \\
\hline Walking & $1122 \pm 068$ & $49.5-5544(693)$ & $1264 \pm 1106$ & $49.5-6930(990)$ & 0.13 \\
\hline Total physical activity & $5018 \pm 209$ & $600-9705(2789)$ & $3829 \pm 2999$ & $223-13044(2448)$ & 0.00001 \\
\hline Time spent sitting & $225 \pm 178$ & $10-800(180)$ & $191 \pm 158$ & $10-720(120)$ & 0.01 \\
\hline
\end{tabular}

The level of education had a significant influence on the level of physical activity in both groups ( $\mathrm{p}<0.01)$. Regarding the means of transportation (physical movement), $52.9 \%$ of the respondents in Group A and $72.8 \%$ in Group B reported low levels of physical activity. The impact of education within the scope of lectures and classes at the UTA had a considerable effect on the analyzed results. We found that $46.6 \%$ of Group A used a bike or walked in their free time and in Group B the surveyed women moved mainly by car, only $15 \%$ by bike or on foot.

\section{Quality of life assessment}

The mean value of PCS was better in Group A than the average in Group B: $53.6 \pm 22.6$ scores (Group A) and $47.3 \pm 19.4$ scores (Group B). The average value of MCS was better in Group A $(55.0 \pm 22.2$ scores $)$ than in Group B (48.4 \pm 19.6 scores). Among the components included in the PCS and MCS, the highest values were recorded in all the domains in Group A (Table III).

Table III. Values of domains of quality of life in studied groups Tabela III. Wartości domen jakości życia w badanych grupach

\begin{tabular}{|c|c|c|c|}
\hline \multirow{3}{*}{ Parameter } & \multicolumn{2}{|c|}{$\begin{array}{l}\text { Investigated women } \\
\text { (percentage score) }\end{array}$} & \multirow{3}{*}{$\begin{array}{l}\text { Statistical } \\
\text { significanc } \\
\text { of } \\
\text { differences } \\
\text { (p) }\end{array}$} \\
\hline & $\begin{array}{r}\text { group A } \\
(n=223)\end{array}$ & $\begin{array}{l}\text { group B } \\
(n=342)\end{array}$ & \\
\hline & mean $\pm S D$ & mean $\pm S D$ & \\
\hline $\begin{array}{l}\text { Physical component } \\
\text { summary (PCS) }\end{array}$ & $53.6 \pm 22.6$ & $47.3 \pm 19.4$ & 0.0004 \\
\hline Physical functioning (PF) & $81.8 \pm 14.8$ & $70.6 \pm 18.3$ & 0.000001 \\
\hline Physical role (PR) & $74.2 \pm 14.0$ & $58.3 \pm 18.9$ & 0.000001 \\
\hline Bodily pain (BP) & $64.4 \pm 16.2$ & $48.4 \pm 20.3$ & 0.000001 \\
\hline General health $(\mathrm{GH})$ & $43.8 \pm 11.0$ & $35.4 \pm 12.8$ & 0.000001 \\
\hline $\begin{array}{l}\text { Mental component summary } \\
\text { (MCS) }\end{array}$ & $55.0 \pm 22.2$ & $48.8 \pm 19.2$ & 0.00042 \\
\hline Emotional role(RE) & $82.4 \pm 9.2$ & $61.2 \pm 16.3$ & 0.000001 \\
\hline Vitality (VT) & $67.0 \pm 8.2$ & $49.3 \pm 13.6$ & 0.000001 \\
\hline Mental health (MH) & $74.7 \pm 9.1$ & $54.9 \pm 14.2$ & 0.001 \\
\hline Social functioning (SF) & $76.3 \pm 8.1$ & $58.5 \pm 16.4$ & 0.0001 \\
\hline
\end{tabular}

There was a statistically significant positive correlation in Group A between the PCS of QoL and age $(\mathrm{R}-$ Spearman $=0.47, \mathrm{p}<0.0001)$, a lack of statistical significance was observed in Group B.

There was a statistically significant correlation between QoL in the PCS domain (R-Spearman $=0.174$, $\mathrm{p}<0.01)$ and MCS domain (R-Spearman $=0.51$, $\mathrm{p}<0.0001)$ and the age of the last menstrual period in Group A.

\section{Quality of life and physical activity}

In Group A a significant correlation was observed in persons with vigorous activity and PCS $(\mathrm{R}=0.32)$, physical functioning $(\mathrm{R}=0.34)$, bodily pain $(\mathrm{R}=-0.12)$, general health $(\mathrm{R}=0.1)$ and social functioning $(\mathrm{R}=0.25)$ (Table IV).

\section{DISCUSSION}

Physical fitness maintained through physical activity is one of the key factors determining proper development of the organism and proper course of the aging process $[12,13]$. People who regularly exercise usually control their weight, eat and sleep better and deal with difficult situations much better. Physical activity is also an important component of the aging process. Exercise taken systematically and at a moderate intensity significantly reduces the consequences of chronic diseases of old age. Therefore, lifestyle modification, change of habits, regular physical activity and a balanced diet can considerably improve the QoL of women in this period. This is an alternative for women to relieve the discomforts of the perimenopausal period $[9,10]$.

Educational programmes aiming at improving and maintaining the health and well-being of citizens are being implemented all over the world. In our own investigations there have been numerous lectures conducted at Universities of the Third Age connected with practical exercises and tips for menopausal women. Education and awareness are a very important 
Table IV. Coefficient correlations of physical activity with domains of quality of life in studied groups Tabela IV. Współczynniki korelacji poziomu aktywności fizycznej i domen jakości życia w badanych grupach

\begin{tabular}{|c|c|c|c|c|c|c|c|c|c|c|c|}
\hline \multirow{2}{*}{\multicolumn{2}{|c|}{ Groups }} & \multicolumn{10}{|c|}{ Domains of quality of life } \\
\hline & & \multirow{2}{*}{$\begin{array}{l}\text { PCS } \\
0.32^{*}\end{array}$} & \multirow{2}{*}{$\begin{array}{c}\text { PF } \\
0.34^{*}\end{array}$} & \multirow{2}{*}{$\begin{array}{c}\text { PR } \\
0.04\end{array}$} & \multirow{2}{*}{$\begin{array}{c}\text { BP } \\
-0.12^{*}\end{array}$} & \multirow{2}{*}{$\begin{array}{c}\text { GH } \\
0.1^{*}\end{array}$} & \multirow{2}{*}{$\begin{array}{l}\text { MCS } \\
0.01\end{array}$} & \multirow{2}{*}{$\begin{array}{c}\text { RE } \\
0.07\end{array}$} & \multirow{2}{*}{$\begin{array}{c}\text { VT } \\
0.01\end{array}$} & \multirow{2}{*}{$\begin{array}{c}\text { MH } \\
0.09\end{array}$} & \multirow{2}{*}{$\frac{\text { SF }}{0.25^{\star}}$} \\
\hline Vlarono phying pativit & A & & & & & & & & & & \\
\hline Vigorous priysical acivily & $B$ & 0.01 & -0.04 & -0.03 & 0.02 & -0.03 & 0.06 & 0.04 & -0.04 & -0.02 & -0.03 \\
\hline \multirow{2}{*}{ Moderate physical activity } & A & 0.12 & 0.05 & $0.16^{*}$ & 0.04 & 0.05 & 0.04 & 0.02 & 0.11 & 0.05 & -0.09 \\
\hline & $B$ & 0.02 & -0.01 & 0.06 & -0.01 & -0.09 & 0.01 & 0.05 & 0.02 & 0.02 & -0.01 \\
\hline \multirow{2}{*}{ Walking } & A & -0.05 & 0.01 & -0.07 & 0.12 & -0.03 & -0.01 & -0.03 & 0.14 & -0.06 & 0.05 \\
\hline & $B$ & 0.001 & 0.04 & -0.04 & 0.03 & 0.01 & -0.01 & 0.03 & -0.05 & -0.07 & 0.05 \\
\hline \multirow{2}{*}{ Total physical activity } & A & $0.2^{*}$ & 0.06 & 0.07 & 0.01 & $0.17^{\star}$ & $0.21^{*}$ & 0.07 & 0.04 & 0.03 & -0.09 \\
\hline & $B$ & -0.03 & 0.01 & 0.06 & -0.07 & 0.06 & -0.07 & -0.01 & -0.006 & -0.02 & 0.01 \\
\hline \multirow{2}{*}{ Time spent sitting } & A & -0.03 & -0.04 & -0.01 & -0.08 & 0.04 & -0.03 & $0.2^{*}$ & 0.03 & -0.03 & $0.16^{*}$ \\
\hline & $B$ & -0.05 & -0.1 & 0.1 & -0.02 & 0.06 & -0.03 & 0.05 & -0.03 & 0.07 & -0.02 \\
\hline
\end{tabular}

${ }^{*} p<0.05$

Abbreviations: $\mathrm{PCS}=$ physical component summary, $\mathrm{PF}=$ physical functioning, $\mathrm{PR}=$ physical role, $\mathrm{BP}=$ bodily pain, $\mathrm{GH}=$ general health, $\mathrm{MCS}=$ mental component summary, $\mathrm{ER}=$ emotional role, $\mathrm{VT}=$ vitality, $\mathrm{MH}=$ mental health, $\mathrm{SF}=$ social functioning

part of a healthy lifestyle. "Health for all in the twenty-first century" has become an important programme for Polish society, as well as the National Health Program 2007-2015 "Increasing physical activity of the population". Although this programme has finished, its recommendations are still relevant. Recommendations regarding physical activity include intense and moderate effort and additional strengthening exercises that should be taken at least twice a week [14]. Important elements of physical activity are regularity and targeted, not random exercises. Universities of the Third Age may have a substantial impact on the awareness of and increase in motivation to undertake intellectual and physical activity, which in turn may translate into improved health and QoL.

Modern women are subjected to constant pressure caused by media focused on active, eternally younglooking women, coping with difficult life situations including the aging process. Therefore, women are looking for methods that will help them in some way to maintain a young appearance and condition. Research by Knapik et al. has shown that an active way of spending leisure time considerably influenced human health and enhanced daily functionality [15]. In our study, physical activity affected both components of health but only in Group A, i.e. among women attending classes at Universities of the Third Age.

According to the recommendations of the Royal College of Obstetricians and Gynaecologists in the United Kingdom and the North American Menopause Society, perimenopausal women should be advised to take up aerobic exercises to relieve menopausal symptoms
$[16,17,18,19]$. An increase in physical activity has positive health consequences including reduced menopausal and postmenopausal symptoms [20,21,22]. In general, the level of physical activity of the surveyed women was satisfactory, based on the obtained results of this study. The highest percentage of respondents with a high level of physical activity was observed among professionally working individuals in Group A.

Regular physical activity is associated with the ability to perform it every day and aids to prevent diseases in old age $[23,24,25,26]$ and it is an essential element of life recommended in the prevention of civilizationrelated ones. The presented material clearly demonstrates the positive impact of participating in classes at Universities of the Third Age on understanding the importance of the problem, and hence taking constructive actions regarding one's health. However, further research is needed to determine other factors influencing the QoL in menopausal women. There is a suggestion that a special programme of physical activity in the menopausal period should be elaborated.

\section{CONCLUSIONS}

Menopausal women participate mainly in moderateintensity physical activity. A vigorous level of physical activity correlates with a better quality of life. Physical activity is very important in everyday life to improve female well-being. 


\section{Author's contribution}

Study design - B. Naworska, A. Drosdzol-Cop

Data collection - B. Naworska

Data interpretation - B. Naworska, A. Drosdzol-Cop

Statistical analysis - B. Naworska, A. Brzęk

Manuscript preparation - B. Naworska, Cz. Marcisz, A. Brzęk, M. Dabrowska-Galas, A. Drosdzol-Cop

Literature research - B. Naworska

Final approval of the version to be published - V. Skrzypulec-Plinta, K. Sodowski

\section{Acknowledgments}

The authors would like to thank Monika Mazurek, Olga Kunc and Marta Majchrzak for helping to introduce some of the data into Exel.

\section{Conflict of interest}

The authors declare no conflicts of interest.

\section{REFERENCES :}

1. Jurakić D., Pedišić Z., Greblo Z. Physical activity in different domain and health-related quality of life: a population-based study. Qual. Life Res. 2010; 19(9): 1303-1309.

2. Blümel J, Fica J, Chedraui P. et al. Sedentary lifestyle in middle-aged women is associated with severe menopausal symptoms and obesity. Menopause 2016; 23, 5: 488-493.

3. Liu S., Manson J.E., Stampfer M.J., Holmes M.D., Hu F.B., Hankinson S.E., Willett W.C. Dietary glycemic load assessed by food-frequency questionnaire in relation to plasma high-density-lipoprotein cholesterol and fasting plasma triacylglycerois in postmenopausal women. Am. J. Clin. Nutr. 2001; 73(3): 560-566

4. Bossemeyer R. Climacteric and menopause: how to prepare women fo upcoming changes (Klimakterium i menopauza: jak przygotować kobiety do czekajacych je zmian). Medicographia 2003; 17: 64-70 [in polish].

5. Unfer T.C., Conterato G.M., da Silva J.C., Duarte M.M., Emanuelli T. Influence of hormone replacement therapy on blood antioxidant enzymes in menopausal women. Clin. Chim. Acta 2006; 369(1): 73-77.

6. Skrzypulec V., Drosdzol A., Ferensowicz J., Nowosielski K. Assessment of the selected aspects of mental and sexual life of women in perimenopausa period (Ocena wybranych aspektów życia psychicznego i seksualnego kobiet w okresie okołomenopauzalnym). Ginekol. Prakt. 2003; 11: 23-34 [in polish].

7. Jaskólski A. The basics of physical activity physiology with the outlines of human physiology (Podstawy fizjologii wysiłku fizycznego z zarysem fizjologii człowieka), AWF. Wrocław 2005 [in polish].

8. Stachoń A., Burdukiewicz A., Pietraszewska J., Andrzejewska J., Chromik K. Biological symptoms of aging in women regarding physical activity and lifestyle. Hum. Mov. 2010; 11: 172-178.

9. Bodera P., Poznański S., Dobrzański P.. Menopause - physiological period in the life of a woman (Menopauza - fizjologiczny okres w życiu kobiety). Przew. Lek. 2005; 74: 76-77 [in polish].

10. Dąbrowska J., Naworska B., Dąbrowska-Galas M., Skrzypulec-Plinta V. Role of physical activity during menopause (Rola wysiłku fizycznego w okresie menopauzy). Przegl. Menopauzalny 2012; 6: 445-448 [in polish]. 11. http://www.institutferran.org/documentos/Scoring_short_ipaq_april04.pdf [dostep: 15.03.2016].

12. Conn V.S., Chan K., Banks J., Ruppar T.M., Scharff J. Cultural relevance of physical activity intervention research with underrepresented populations. Int. Q. Community Health Educ. 2013; 34(4): 391-414.

13. Conn V.S., Hafdahl A.R., Mehr D.R. Interventions to increase physica activity among healthy adults: meta-analysis of outcomes. Am. J. Public Health 2011; 101(4): 751-758.

14. Gawron B., Kowalski R. Physical activity - a healthy lifestyle of children, infants and adults (Aktywność fizyczna - zdrowym stylem życia dzieci i młodzieży i osób dorosłych). Sport dla wszystkich: strategia rozwoju sportu dla wszystkich 2011-2012; 41-42 [in polish].

15. Knapik A., Saulicz E., Kuszewski M., Plinta R. An analysis of relations between a self-assessment of health an active life-style. Med. Sport. 2009; 13(1): 17-21.

16. North American Menopause Society. Treatment of menopause-associated vasomotor symptoms: position statement of the North American Menopause Society. Menopause 2004; 11(1): 11-33.

17. Alternatives to HRT for the management of symptoms of the menopause. Royal College of Obstetricians and Gynaecologists. Scientific Advisory Committee. Opinion paper 2004; 6.

18. Jeng C., Yang S.H., Chang P.C., Tsao L.I. Menopausal women: perceiving continuous power through the experience of regular exercise. J. Clin. Nurs. 2004; 13(4): 447-454

19. Skrzypulec V., Dabrowska J., Drosdzol A. The influence of physical activity level on climacteric symptoms in menopausal women. Climacteric 2010; 13(4): 355-361.

20. Morss G.M., Jordan A.N., Skinner J.S., Dunn A.L., Church T.S., Earnest C.P., Kampert J.B., Jurca R., Blair S.N. Dose Response to Exercise in Women aged 45-75 yr (DREW): design and rationale. Med. Sci. Sports Exerc. 2004; 36(2): 336-344.

21. Conroy D.E., Hyde A.L., Doerksen S.E., Ribeiro N.F. Implicit attitudes and explicit motivation prospectively predict physical activity. Ann. Behav. Med. 2010; 39(2): 112-118

22. Pines A., Berry E.M. Exercise in the menopause - an update. Climacteric 2007; 10 (Suppl 2): 42-46.

23. da Silva R.B., Costa-Paiva L., Pinto-Neto A.M., de Braga A., Morais S.S. Association between habitual physical activity and parameters of physical fitness in postmenopausal women. Climacteric 2005; 8(4): 360-370.

24. Dąbrowska J., Dąbrowska-Galas M., Rutkowska M., Michalski B. Twelve-week exercise training and the quality of life In menopausal women clinical trial. Menopause Rev. 2016: 15(1): 20-25.

25. Peterson M.J., Giuliani C., Morey M.C., Pieper C.F., Evenson K.R., Mercer V., Cohen H.J., Visser M., Brach J.S., Kritchevsky S.B., Goodpaster B.H., Rubin S., Satterfield S., Newman A.B., Simonsick E.M. Physical activity as a preventative factor for frailty: the health, aging, and body composition study. J. Gerontol. A Biol. Sci. Med. Sci. 2009; 64(1): 61-68.

26. Walczak A., Wiśniewska B. Psychosocial aspects of women's functioning during postmenopausal period - preliminary studies (Psychospołeczne aspekty funkcjonowania kobiet $\mathrm{w}$ okresie postmenopauzalnym - badania wstępne). Prz. Menopauz. 2012; 11(6): 474-477. 